\title{
MOLECULAR DETECTION AND IDENTIFICATION OF COXIELLA BURNETII IN ABORTED SHEEP AND GOATS IN SULAIMANI PROVINCE, KURDISTAN-IRAQ
}

\author{
FATTAH MARIF HARDI ${ }^{1}$; HANA SHERZAD RAUF ${ }^{1}$; SHAKHAWAN LATIF MAHMOOD ${ }^{1}$; \\ REBWAR BAHIR AHMAD ${ }^{1}$; BASIM ABDULWAHID ALI ${ }^{1}$ \\ AND MOHAMED OMAR BABA SHEIKH ${ }^{2}$ \\ ${ }^{1}$ College of Veterinary Medicine, University of Sulaimani, New Sulaimani, Street 27, Sulaymaniyah, \\ Kurdistan Region, Northern Iraq \\ ${ }^{2}$ Directorate of Veterinary in Sulaimani, Salim Street, Sulaimaniyah, Kurdistan Region, Iraq
}

Received: 31 December 2019; Accepted: 31 January 2020

\begin{abstract}
Q fever is an almost ubiquitous zoonotic disease with a worldwide distribution, caused by Coxiella burnetii which can infect different types of animal species such as cattle, sheep and goats, as well as humans. Infection with $C$. burnetii in small ruminants, are mostly sub-clinical, although, abortions and stillbirths can occur. The aim of this study was to provide molecular evidence of $C$. burnetii in aborted small ruminants in different districts of Sulaimani province, Kurdistan-Iraq. Blood and faecal samples were collected from 180 aborted sheep and goats (90 samples each) and analyzed by conventional Polymerase Chain Reaction (PCR) for DNA detection of transposase gene (IS1111) of C. burnetii from February to June 2019. (Comparison sequence analysis exhibit that field isolates highest identities of (Iraq, Iran and China) strains with the rate of 99.84\%). Shedding of $C$. burnetii by aborted sheep and goats was found only in (5.55\%) faecal samples investigated. Only 10 out of 60 faecal samples (16.66\%) were positive. Six out of 48 faecal samples (12.5\%) and 5 out of 12 faecal samples $(41.66 \%)$ were positive in aborted sheep and goats respectively. None of the blood samples revealed positive amplification for $C$. burnetii DNA. This paper documents the first molecular detection of $C$. burnetii in aborted small ruminants in Sulaimani province Kurdistan-Iraq.
\end{abstract}

Keywords: Coxiella burnetii, Q fever, Sulaimani province, PCR and zoonotic disease.

\section{INTRODUCTION}

Q fever is a zoonotic disease in humans and animals affecting a wide range of hosts. The causative agent, Coxiella burnetii, is a Gram-negative obligate intracellular bacterium and is known for its high tenacity and infectivity present worldwide (Heinzen, et al., 1999), (McCaul \& Williams, 1981), (Aitken et al., 1987).

Reservoirs of $C$. burnetii include many wild and domesticated mammals, birds and ticks (Raoult, et $a l ., 2005)$. Ticks are considered to be the natural primary reservoirs of $C$. burnetii responsible for the spread of the infection in wild animals and for transmission to domestic animals (Norlander, 2000). In animals, $C$. burnetii infection does not usually provoke severe symptoms. However, in cattle it has

Corresponding author: Dr. FATTAH MARIF HARDI

E-mail address: hardi.marif@univsul.edu.iq

Present address: College of Veterinary Medicine, University of Sulaimani, New Sulaimani, Street 27, Sulaymaniyah, Kurdistan Region, Northern Iraq been associated with infertility and in small ruminants (goats and sheep) the infection can result in late abortions. Increased abortion rates in infected caprine herds have been described, with up to $90 \%$ abortions in pregnant animals (Van den Brom, van Engelen, Roest, van der Hoek, \& Vellema, 2015). Infected females shed a huge amount of bacteria in birth products and in urine, feces, and milk. This shedding can persist for several months in vaginal mucus, feces, and milk (Rodolakis, 2009). The massive shedding of $C$. burnetii during such abortions makes sheep and goats the main reservoirs responsible for infection of humans (Parisi et al., 2006).

C. burnetii is most often transmitted to humans by inhalation of an aerosol that has been contaminated with parturient products, urine, and feces of the infected animals (Parisi et al., 2006). Main clinical presentations may be as flu- like illness or a febrile pneumonia or hepatitis (Arricau-Bouvery \& Rodolakis, 2005), (Kampschreur et al., 2012), While, in few cases, the disease progresses to a chronic stage characterized by endocarditis or vascular infection (Kampschreur et al., 2012), (Raoult et al., 2005), (Anderson et al., 2013). Polymerase Chain Reaction (PCR) assays are commonly used to directly detect $C$. 
burnetii in biological materials such as placentas, genital swabs, feces or milk samples, and reveal the existence of ongoing infections associated with bacterial shedding (Norlander, 2000). PCR assays provide a valuable approach that is sensitive, easy to perform, and safe for laboratory personnel and it holds the promise of timely diagnosis, since it should be positive before antibodies are detectable (Berri, et al., 2003).

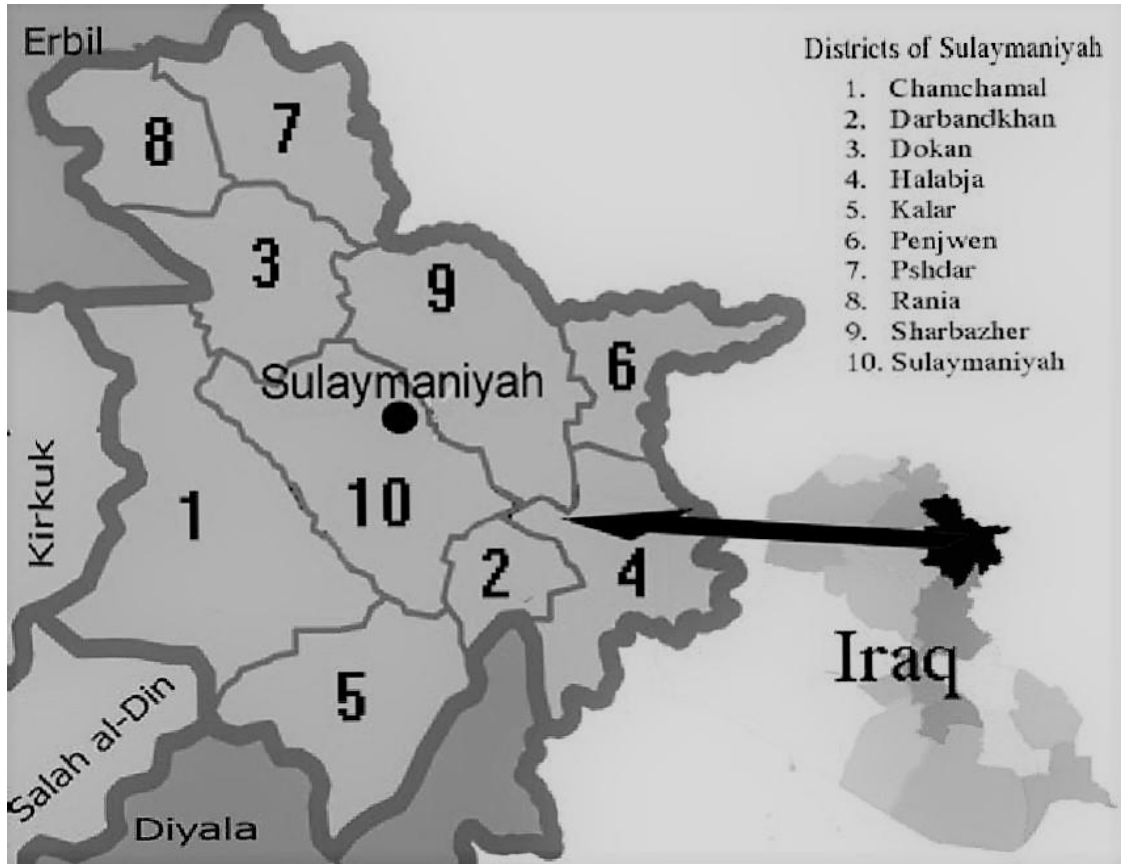

Figure 1: Area of the research, samples were taken from different districts of Sulaimani province, KurdistanIraq.

\section{MATERIALS AND METHODS}

\section{Sample collection}

This study was carried out from February to June 2019. Blood and fecal samples were collected from 90 sheep and 90 goats. Blood $(5 \mathrm{ml})$ was collected from the jugular veins of the aborted small ruminants using disposable needles (18 gauges) and $10 \mathrm{ml}$ syringes. Blood samples were then stored at room temperature for one hour to allow clotting. After centrifugation $(1,500 \mathrm{x} \mathrm{g}, 10$ minutes $)$ the serum samples were ready for DNA extraction.

Fecal (3g) was obtained and placed in sterile plastic tubes, transported to the laboratory at $4^{\circ} \mathrm{C}$ and subsequently preserved at $-20^{\circ} \mathrm{C}$.

\section{Sample preparation and DNA extraction}

The fecal samples were vortexed in phosphate buffered saline (1 mL $0.1 \mathrm{M}$ PBS of $\mathrm{pH} 7)$, then genomic DNA was extracted from fecal and serum specimens using a DNA extraction kit (Genaild, Co, Korea) according to the manufacturer's instructions.

\section{Oligonucleotide primer}

A PCR protocol targeting IS1111 repetitive transposon-like region of $C$. burnetii was used for the detection of $C$. burnetii DNA in feces and serum. For the PCR amplification primers Trans-1 (5'-TAT GTA TCC ACC GTA GCC AGT C-3') and Trans-2 (5'CCCAAC AAC ACC TCC TTA TTC-3') were used (Hernychova et al., 2008). The length of the genome target for amplification was expected to be (687) bp (table 1).

Table 1: Sequences of primers and PCR conditions

\begin{tabular}{|c|c|c|c|c|c|c|c|c|}
\hline \multirow[b]{2}{*}{ Protocol } & \multirow[b]{2}{*}{ Primer } & \multirow[b]{2}{*}{ Sequence } & \multirow[b]{2}{*}{ Gene } & \multirow{2}{*}{$\begin{array}{l}\text { Amplifier } \\
\text { length } \\
\text { (bp) }\end{array}$} & \multicolumn{4}{|c|}{ PCR conditions $\left({ }^{\circ} \mathrm{C} / \mathrm{s}\right)$} \\
\hline & & & & & Denaturation & Annealing & Extension & $\begin{array}{l}\text { No. of } \\
\text { PCR } \\
\text { cycles }\end{array}$ \\
\hline \multirow{2}{*}{$\begin{array}{c}\text { Uniplex } \\
\text { Polymerase } \\
\text { Chain } \\
\text { Reaction }\end{array}$} & Trans-1 & $\begin{array}{c}\text { 5'-TAT GTA } \\
\text { TCC ACC GTA } \\
\text { GCC AGT C-3' }\end{array}$ & IS1111 & 687 & $95 / 30$ & $58 / 35$ & $72 / 40$ & \\
\hline & Trans-2 & $\begin{array}{c}\text { 5'-CССAAC } \\
\text { AАC АСС ТCC } \\
\text { TTA TTC-3' }\end{array}$ & IS1111 & 687 & $95 / 30$ & $58 / 35$ & $72 / 40$ & 40 \\
\hline
\end{tabular}




\section{Uniplex Polymerase Chain Reaction}

C. burnetii was amplified by using PCR Premix (2X). This kit provides a complete system for fast, high yield and reliable single tube PCR (Genet-bio, Korea). The reactions were carried out in $0.2 \mathrm{ml} \mathrm{PCR}$ tube based on the following specifications: $10 \mu \mathrm{L}$ supreme script PCR premix, $5 \mu \mathrm{L}$ DNA, $1 \mu \mathrm{L}$ forward (10 pmol), $1 \mu \mathrm{L}$ reverse primers $(10 \mathrm{pmol})$, and $3 \mu \mathrm{L}$ ultra-pure water to make up a final volume of $20 \mu \mathrm{L}$. The conventional PCR machine (Hercuvan, USA) was programmed as followed: initial denaturation at $95^{\circ} \mathrm{C}$ for $10 \mathrm{~min}$ followed by 40 cycles of $95^{\circ} \mathrm{C}$ for $30 \mathrm{~s}$; annealing at $58^{\circ} \mathrm{C}$ for $35 \mathrm{~s}$, and extension at 72 ${ }^{\circ} \mathrm{C}$ for $40 \mathrm{~s}$ and a final extension at $72{ }^{\circ} \mathrm{C}$ for $10 \mathrm{~min}$. Five microliters of each amplified DNA sample were loaded on to a $1 \%$ agarose gel stained with a safe dye (Eurx-poland) on preparation. Electrophoresis was performed at $100 \mathrm{~V}$ for 50 minutes.

\section{Sequencing the PCR products}

In order to confirm the PCR results, sequencing method was depended, $25 \mu$ of amplified PCR product of two positive samples with both direction primers were sent for sequencing using Sanger sequencing method (Macrogen, South Korea).The results were submitted in NCBI/ GenBank with accession number (MK994501 \& MK994502).

\section{Phylogenetic tree and sequence analysis}

Phylogenetic trees were constructed based on partial sequence IS1111A transposase gene 26 strain of $C$. burentii. The sequence homology and multiple sequences alignment at the nucleotide and amino acid level was performed by the CLUSTALW program (Thompson, et al., 1994), the phylogenetic tree was constructed by MEGA.X program employing the neighbor-joining (NJ) method (Kimura, 1980), (Kumar, et al., 2018).

\section{RESULTS}

Positive amplification was obtained, using the primers which amplify the repetitive transposon-like regions of $C$. burnetii, from 10 out of 180 blood and faecal samples with $5.55 \%$ investigated in the present study. None of the blood samples collected from aborted sheep and goats revealed positive amplification for $C$. burnetii DNA. Shedding of $C$. burnetii by aborted small ruminants was found only in 10 out of 60 faecal samples $(16.66 \%)$ investigated. Six out of 48 faecal samples $(12.5 \%)$ and 5 out of 12 faecal samples $(41.66 \%)$ were positive in aborted sheep and goats respectively (table 2 ).

Table 2: PCR results of examined blood and fecal samples in aborted sheep and goats according to places in Sulaimani province, Kurdistan-Iraq.

\begin{tabular}{|c|c|c|c|c|c|c|c|}
\hline \multicolumn{8}{|c|}{ Animals } \\
\hline \multirow{2}{*}{ No. } & \multirow[b]{2}{*}{ Districts } & \multicolumn{3}{|c|}{ Sheep } & \multicolumn{3}{|c|}{ Goats } \\
\hline & & $\begin{array}{c}\text { Blood } \\
\text { samples }\end{array}$ & $\begin{array}{c}\text { Fecal } \\
\text { samples }\end{array}$ & PCR+ (\%) & $\begin{array}{c}\text { Blood } \\
\text { samples }\end{array}$ & $\begin{array}{c}\text { Fecal } \\
\text { samples }\end{array}$ & PCR+ (\%) \\
\hline 1. & Chamchamal & 4 & - & $0(0 \%)$ & 6 & - & $\mathbf{0}(\%)$ \\
\hline 2. & Darbandikhan & 3 & - & $0(0 \%)$ & 2 & - & $0(\%)$ \\
\hline 3. & Dokan & 3 & - & $\mathbf{0}(\mathbf{0 \%})$ & 3 & - & $\mathbf{0}(\%)$ \\
\hline 4. & Halabja 1 & 4 & - & $0(0 \%)$ & 4 & - & $0(\%)$ \\
\hline 5. & Kalar & 5 & - & $0(0 \%)$ & 11 & - & $0(\%)$ \\
\hline 6. & Penjwen & 1 & - & $0(0 \%)$ & 11 & - & $\mathbf{0}(\%)$ \\
\hline 7. & Pshdar & 3 & - & $0(0 \%)$ & 2 & - & $\mathbf{0}(\%)$ \\
\hline 8. & Rania 1 & 5 & - & $0(0 \%)$ & 7 & - & $\mathbf{0}(\%)$ \\
\hline 9. & Sharbazher 1 & 2 & - & $0(0 \%)$ & 9 & - & $\mathbf{0}(\%)$ \\
\hline 10. & Sulaymaniyah & 3 & - & $\mathbf{0}(\mathbf{0 \%})$ & 5 & - & $\mathbf{0}(\%)$ \\
\hline 11. & Halabja 2 & 2 & - & $0(0 \%)$ & 9 & - & $\mathbf{0}(\%)$ \\
\hline 12. & Sharbazher 2 & 3 & - & $0(0 \%)$ & 3 & - & $\mathbf{0}(\%)$ \\
\hline 13. & Rania 2 & 4 & - & $\mathbf{0}(\%)$ & 6 & - & $\mathbf{0}(\%)$ \\
\hline 14. & Kalar & & 6 & $2(33.33 \%)$ & - & 4 & $2(50 \%)$ \\
\hline 15. & Penjwen & - & 10 & $1(10 \%)$ & - & 6 & $1(16.6 \%)$ \\
\hline 16. & Pshdar & - & 32 & $3(9.375 \%)$ & - & 2 & $1(50 \%)$ \\
\hline Total & & 42 & 48 & & 78 & 12 & 180 \\
\hline
\end{tabular}




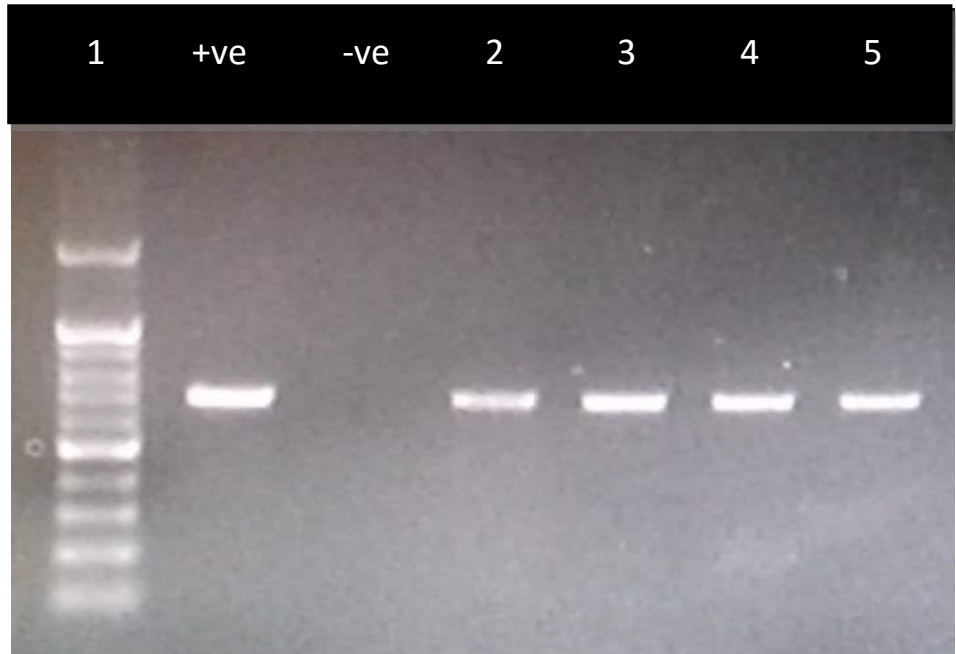

Figure 2: lane 1: 100 bp DNA ladder, +ve: positive control, -ve: negative control, lanes (2-5): an example of positive samples.

\section{Sequence and phylogenetic tree analysis}

Nucleotide and amino acid identity of different countries of partial sequence IS1111A transposase gene were compared with other fourteen $C$. burentii strains. Field sequences strain exhibited identities ranging from 96.82 to $99.84 \%$, and the highest similarity with (Iran, Brazil, Iraq and China) strain with identity rate of $99.84 \%$, and lowest identity with Algeria strain with identity $96.82 \%$. A comparative analysis of the two field isolates exhibited a $100 \%$ identity to each other. Interestingly, these isolates presented very limit amino acid diversity from other country strain except Nigeria and Namibia strain ranging from $1.51-20.0 \%$. The partial sequence IS1111A transposase gene of both field sequences were aligned and compared with the reference strains for sequence analysis (Fig. 3), transposaese protein revealed limited variation between them (only one or two amino acid changed) except Namibia and Negeria strain due to different origin (Fig. 3). In phylogenic tree is shown in (Fig. 4), the two sequence of field isolate clustered together and make grouped with Brazil, Portugal and china strain.

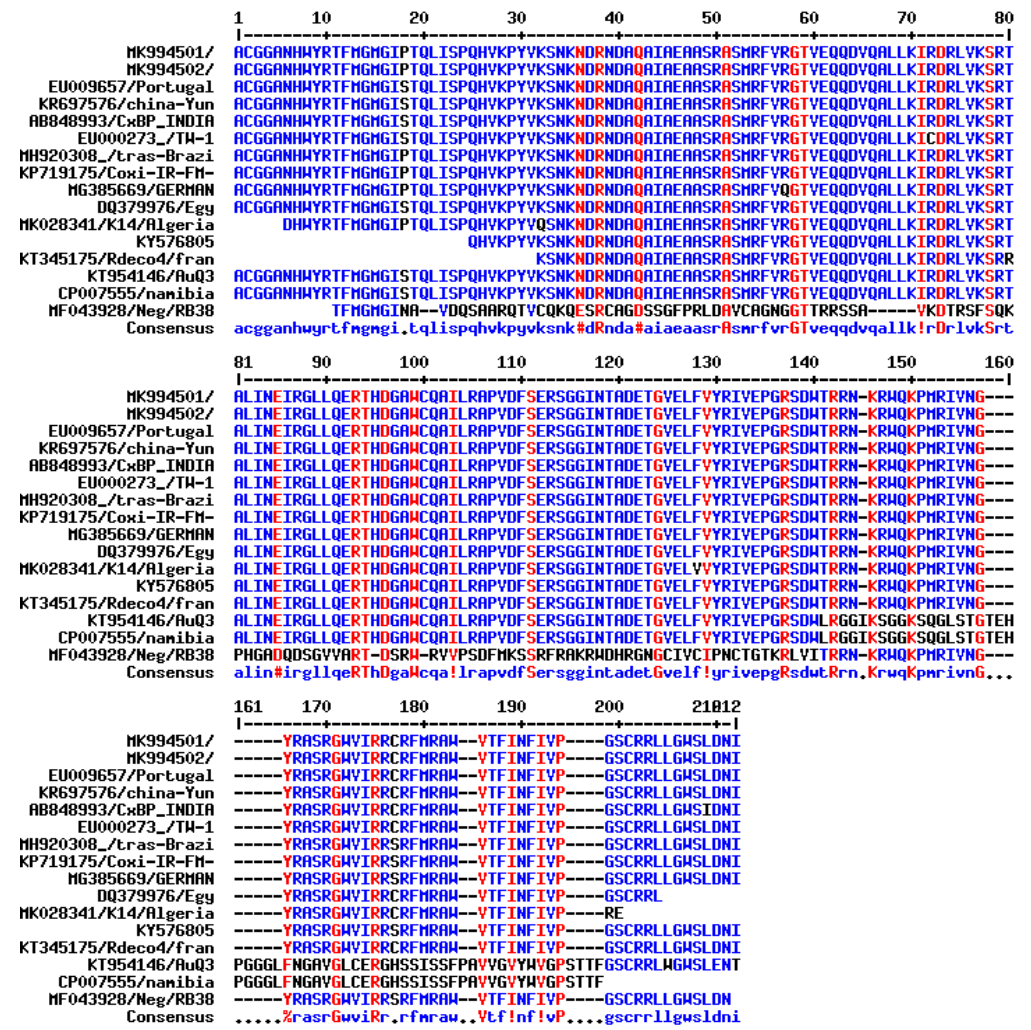

Figure 3: Two fields isolate sequences alignment with differences reference. Multiple sequences alignment of the amino acid of transpoanes gene region two fields isolates Coxiella burentii with fourteen reference strain in different countries. 


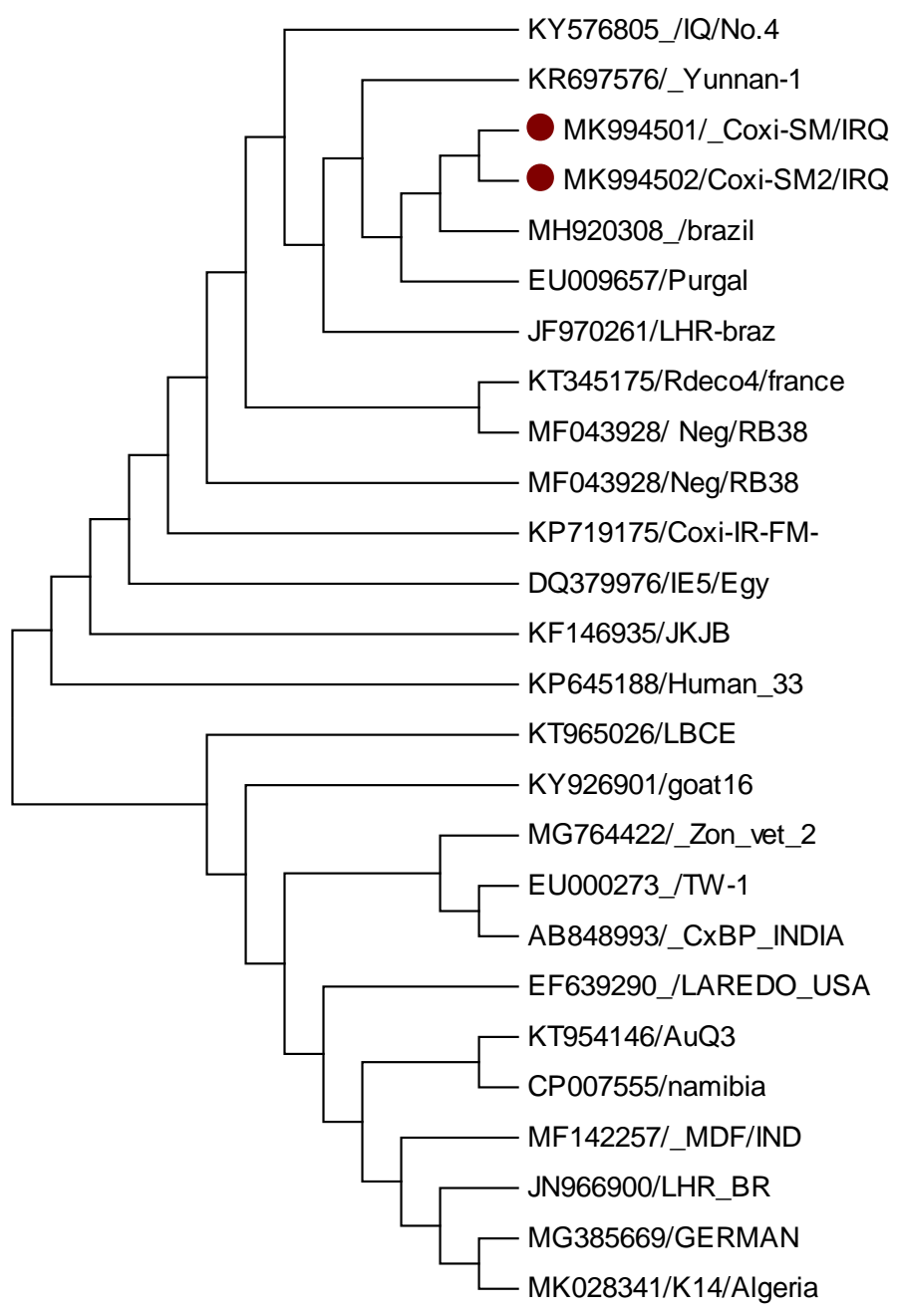

Figure 4: Neighbor-joining (NJ) phylogenetic tree generated using the nucleotide sequences for the partial sequence transpaneas gene of coxiella burentii spp.

\section{DISCUSSION}

The amplification of transposase gene (IS1111) allowed for the sensitivity of the assay to be increased, because this is a multi-copy gene (7-110 copies) (Klee et al., 2006). DNA sequences generated in the present study confirm that $C$. burnetii is circulating in goats and sheep from some herds of Sulaimani province. A few studies were conducted on C. burnetii in Iraq. An outbreak of Q fever occurred with high morbidity in U.S. marines located in Iraq (Faix et al., 2008).

The circulation of $C$. burnetii has been reported in AL- Diwaniayh city of Iraq in 2017. The current study constitutes the second attempt to genotype $C$. burnetii strains in Iraq. Certainly much more work needs to be done and many more samples need to be tested in order to record as many different genotypes as possible, as well as, to cover most of the country territory. Furthermore, the collection of such data and their comparison with data deposited in international databases will help towards both the continuing of the active surveillance and strain genotyping of the pathogen.

Q fever cases have been reported from some countries neighboring Iraq, such as Turkey and Iran. Results of a serosurvey undertaken on 42 sheep flocks in Turkey showed that $20 \%$ of sheep were seropositive (Kennerman, et al., 2010). Serologic evidences indicate people and animals in Iran are exposed to C. burnetii (Khalili \& Sakhaee, 2009), (Khalili, et al., 2010).

C. burnetii has already been detected using different PCR methods in blood samples of infected camels in Iran (Schoffelen et al., 2014).The sequence results analysis revealed $99 \%$ identity with Iranian, Brazilian and china strains. This indicates that the source of the bacteria in Iraq is Iran, Brazil and China which entered the country by importing meat and animal products from these countries.

Limited variation between field sequences, past Iraqi strain, and other countries is an indicator for stability 
of transposase gene (Fig. 3). In phylogenetic tree the sequences of current study make cluster with other Iraqi strain, this result epidemiologically exhibit that Coxiella burnetii has the same source in Iraq (fig. 4). The main route of shedding by ovine was found to be the faeces and vaginal mucus, while these routes were rare in bovine herds. Caprines were found to shed the organism via vaginal discharges, faeces and milk (Rodolakis et al., 2007).

Shedding of $C$. burnetii in goats via faeces lasted for 2-5 weeks. In the present study the absence of $C$. burnetii DNA from the serum samples of sheep and goats could be attributed to the fact that the organism in these animal species is shed primarily via vaginal mucus and faeces, and this probably confirms that milk and blood are not the preferred routes of discharge for $C$. burnetii in sheep and goats (Rodolakis et al., 2007).

\section{CONCLUSION}

The present study reports the first molecular detection of $C$. burnetii in sheep and goat in Sulaimani province. Further studies are necessary to characterize the genotype of $C$. burnetii and to identify the potential risk of transmission between human and animals regarding the public health issue of $Q$ fever.

\section{ACKNOWLEDGEMENT}

Authors are thankful to the Sulaimani Veterinary Diagnostic Laboratory (SVDL) for providing facilities to carry out this research word.

\section{CONFLICT OF INTEREST}

The authors disclose no conflict of interest.

\section{REFERENCES}

Aitken, I.D.; Bogel, K.; Cracea, E.; Edlinger, E.; Houwers, D. and Krauss, H. (1987): Q fever in Europe: current aspects of aetiology, epidemiology, human infection, diagnosis and therapy. Infection, 15(5), 323-327. doi: 10.1007/bf01647731.

Anderson, A.; Bijlmer, H.; Fournier, P.E.; Graves, S.; Hartzell, J.; Kersh, G.J. and Sexton, D.J. (2013): Diagnosis and management of Q fever--United States, 2013: recommendations from CDC and the Q Fever Working Group. MMWR Recomm Rep, 62(RR-03), 1-30.

Arricau-Bouvery, N. and Rodolakis, A. (2005): Is Q fever an emerging or re-emerging zoonosis? Vet Res, 36(3), 327-349. doi: 10.1051/ vetres:2005010.

Berri, M.; Arricau-Bouvery, N. and Rodolakis, A. (2003): PCR-based detection of Coxiella burnetii from clinical samples. Methods Mol
Biol, 216, 153-161. doi: 10.1385/1-59259-3445:153.

Faix, D.J.; Harrison, D.J.; Riddle, M.S.; Vaughn, A.F.; Yingst, S.L.; Earhart, K. and Thibault, G. (2008): Outbreak of Q fever among US military in western Iraq, June-July 2005. Clin Infect Dis, 46(7), e65-68. doi: 10.1086/528866.

Heinzen, R.A.; Hackstadt, T. and Samuel, J.E. (1999): Developmental biology of Coxiella burnettii. Trends Microbiol, 7(4), 149-154. doi: 10.1016/s0966-842x(99)01475-4.

Hernychova, L.; Toman, R.; Ciampor, F.; Hubalek, M.; Vackova, J.; Macela, A. and Skultety, L. (2008): Detection and identification of Coxiella burnetii based on the mass spectrometric analyses of the extracted proteins. Anal Chem, 80(18), 7097-7104. doi: 10.1021/ac800788k.

Kampschreur, L.M.; Dekker, S.; Hagenaars, J.C.; Lestrade, P.J.; Renders, N.H.; De JagerLeclercq, M.G. and Oosterheert, J.J. (2012): Identification of risk factors for chronic $Q$ fever, the Netherlands. Emerg Infect Dis, 18(4), 563-570. doi: 10.3201/eid1804.111478.

Kennerman, E.; Rousset, E.; Golcu, E. and Dufour, $P$. (2010): Seroprevalence of Q fever (coxiellosis) in sheep from the Southern Marmara Region, Turkey. Comp Immunol Microbiol Infect Dis, 33(1), 37-45. doi: 10.1016/j.cimid.2008.07.007.

Khalili, M. and Sakhaee, E. (2009): An update on a serologic survey of $\mathrm{Q}$ Fever in domestic animals in Iran. Am J Trop Med Hyg, 80(6), 1031-1032.

Khalili, M.; Shahabi-Nejad, N. and Golchin, M. (2010): Q fever serology in febrile patients in southeast Iran. Trans R Soc Trop Med Hyg, 104(9), 623-624. doi: $10.1016 /$ j.trstmh.2010.04.002.

Kimura, M. (1980): A simple method for estimating evolutionary rates of base substitutions through comparative studies of nucleotide sequences. J Mol Evol, 16(2), 111-120. doi: 10.1007/bf01731581.

Klee, S.R.; Tyczka, J.; Ellerbrok, H.; Franz, T.; Linke, S.; Baljer, G. and Appel, B. (2006): Highly sensitive real-time PCR for specific detection and quantification of Coxiella burnetii. BMC Microbiol, 6, 2. doi: 10.1186/1471-2180-6-2.

Kumar, S.; Stecher, G.; Li, M.; Knyaz, C. and Tamura, K. (2018): MEGA X: Molecular Evolutionary Genetics Analysis across Computing Platforms. Mol Biol Evol, 35(6), 1547-1549. doi: 10.1093/molbev/msy096.

McCaul, T.F. and Williams, J.C. (1981): Developmental cycle of Coxiella burnetii: structure and morphogenesis of vegetative and sporogenic differentiations. $J$ Bacteriol, 147(3), 1063-1076. 
Norlander, L. (2000): Q fever epidemiology and pathogenesis. Microbes Infect, 2(4), 417-424.

Parisi, A.; Fraccalvieri, R.; Cafiero, M.; Miccolupo, A.; Padalino, I.; Montagna, C. and Sottili, $R$. (2006): Diagnosis of Coxiella burnetii-related abortion in Italian domestic ruminants using single-tube nested PCR. Vet Microbiol, 118(12), 101-106. doi: 10.1016/j.vetmic.2006. 06.023 .

Raoult, D.; Marrie, T. and Mege, J. (2005): Natural history and pathophysiology of Q fever. Lancet Infect Dis, 5(4), 219-226. doi: 10.1016/S1473-3099(05)70052-9.

Rodolakis, A. (2009): Q Fever in dairy animals. Ann $N \quad Y$ Acad Sci, 1166, 90-93. doi: 10.1111/j.1749-6632.2009.04511.x

Rodolakis, A.; Berri, M.; Hechard, C.; Caudron, C.; Souriau, A., Bodier, C.C. and ArricauBouvery, N. (2007): Comparison of Coxiella burnetii shedding in milk of dairy bovine, caprine, and ovine herds. J Dairy Sci, 90(12), 5352-5360. doi: 10.3168/jds.2006-815.
Schoffelen, T.; Limonard, G.J.; Bleeker-Rovers, C.P.; Bouwman, J.J.; Van Der Meer, J.W.; Nabuurs-Franssen, $M$. and Van Deuren, $M$. (2014): Diagnosis of Coxiella burnetii infection: comparison of a whole blood interferon-gamma production assay and a Coxiella ELISPOT. PLoS One, 9(8), e103749. doi: 10.1371/journal.pone.0103749.

Thompson, J.D.; Higgins, D.G. and Gibson, T.J. (1994): CLUSTAL W: improving the sensitivity of progressive multiple sequence alignment through sequence weighting, position-specific gap penalties and weight matrix choice. Nucleic Acids Res, 22(22), 4673-4680. doi: 10.1093/nar/22.22.4673.

Van den Brom, R.; Van Engelen, E.; Roest, H.I.; Van Der Hoek, W. and Vellema, P. (2015): Coxiella burnetii infections in sheep or goats: an opinionated review. Vet Microbiol, 181(12), 119-129. doi: 10.1016/j.vetmic. 2015 . 07.011 .

\section{الكثف الجزئي وتحديد الإصابة ب Coxiella burnetii في الاغنام والماعز المجهضة في محافظة السليمانية- كردستان- العراق في الاق

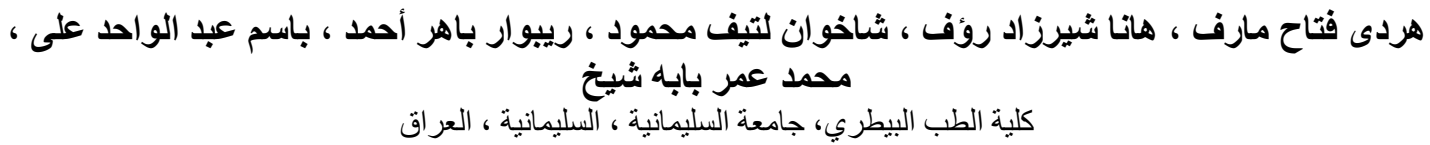

E-mail: hardi.marif@univsul.edu.iq Assiut University web-site: www.aun.edu.eg

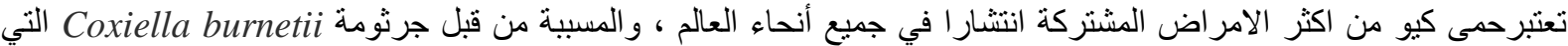

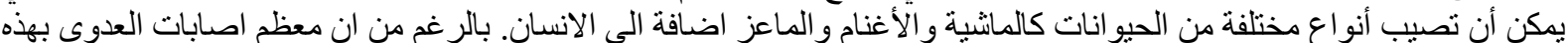

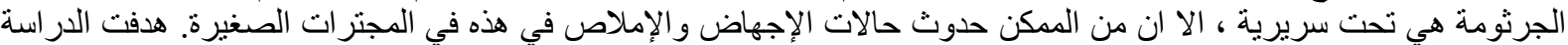

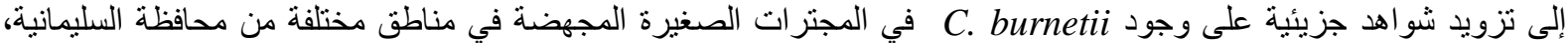

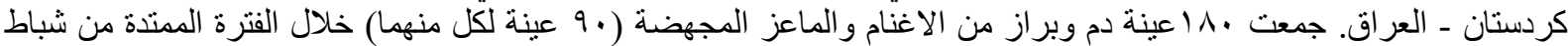

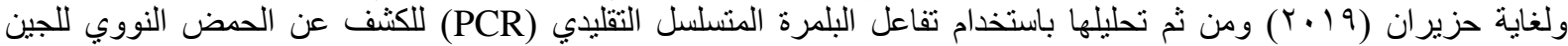

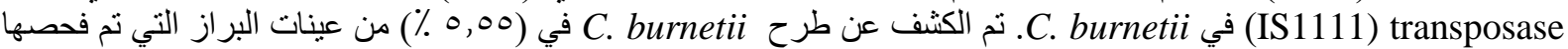

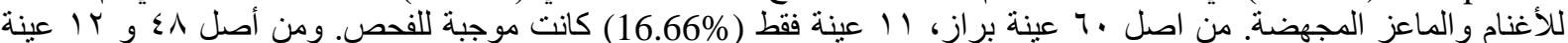

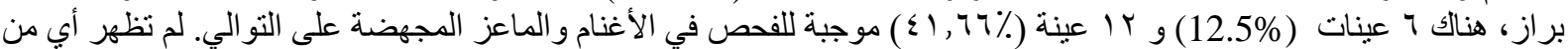

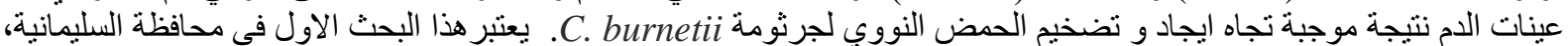

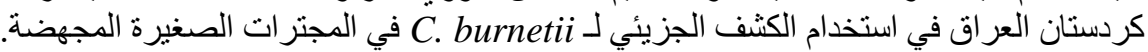

